https://doi.org/10.52837/27382702-2021-34.2-13

\title{
A SHORT STORY OF MULLAH NASREDDIN IN THE ANBARĀNI DIALECT OF THE TALYSHI LANGUAGE: TEXT, TRANSLATION, GLOSSARY AND COMMENTS*
}

\author{
Hakob Avchyan
}

\begin{abstract}
Talyshi, classified as belonging to the Northwestern Iranian group of languages, includes a wide range of dialects, which, based on phonological, grammatical and lexical factors, are traditionally divided into three main clusters: Northern, Central and Southern (see Bazin 1980; Stilo 1981; Yarshater 1996). Anbarāni is a Northern Talyshi dialect spoken in Anbarān district (bax̌̌) of Namin sub-provincial district (šahrestān) (Ardabil province) of Iran, in the city of Anbarān and adjacent villages. Relatively a large number of studies deal with the Northern Talyshi dialects spoken in the Republic of Azerbaijan. For example, "The Talyshi Texts" by Professor of Iranian Studies Boris Miller, includes short stories, anecdotes, conversations, poetic verses (see Miller 1930) written down in these dialects. Unlike the Northern Talyshi dialects spoken in the Republic of Azerbaijan, the Anbarāni dialect is little known and less studied therefore the number of texts, published in this dialect, is quite limited. The aim of this paper is to broaden the scope of knowledge on Anbarāni by introducing a short story of Mullah Nasreddin and analyzing a number of morphological, syntactical and lexical dialectal features based on the text.
\end{abstract}

Keywords: Talyshi, Northern Talyshi, Anbarāni, Iranian languages, linguistics, dialectology.

\section{Introduction}

This text is one of the four short stories of Mullah Nasreddin in the Anbarāni dialect recorded in Aminjān ${ }^{1}$ in May, 2017 from Safā yamxāri, a 55 years old independent contractor (peymānkār) with a perfect knowledge of his mother tongue. According to the respondent, the story was told by her mother when he was a child. The reccording is 32 seconds in length and was written down and transcribed with the help of Sinā Morādzādeh, a 20 years old student of the University of Mohaghegh Ardabili, who also has a perfect command of his mother

\footnotetext{
* The article was submitted on November 3, 2021. The article was reviewed on November 15, 2021. This article has been written during my research stay in summer 2017 at Hamburg University supported by DAAD (Deutscher Akademischer Austauschdienst). I would like to express my sincer gratitude to Prof. Vardan Voskanyan for his support and professional advice, to Prof. Dr. Ludwig Paul for valuable comments and helpful suggestions, as well as to Noonik Darbinian for editing the English text.

${ }^{1}$ Nowadays the former Aminjān village is a part of the town of Anbarān which was created in 1998 by uniting this village with Anbarān-e Soflā (Bazin 2012).
} 
tongue and was my main informant during the fieldwork conducted in June-July 2015 .

\section{Text: "Veyza do"}

i ruž Mallo ča veyza do žio həta bə ki i karanda gəle veyz agənina ča sasa. Čayo šuruš kā ba šukr kārde ki i nafar čayo davāna bə. A vāxti ki yaziyaš zəna ba Malloš vote: əmə ki šukr kārdeš pinani. Mallo vote: hāy āxmax, zənaniš ki agar ča veyza do avaz gəle xāmza do abi ba čəmān sa če baloyi avoyi.

\section{Translation: "The Walnut Tree"}

One day Mullah was sleeping under the walnut tree that[when] suddenly a walnut fall on the head. Then Mullah began to thank [The God], and a person was passing. When he learned about the incident he said to Mullah: Well, there is no need to thank [The God]. Mullah said: "Hey, fool! You don't know if [it] was a melon tree instead of the walnut tree, what a trouble it would bring.

\section{Glossary and comments}

4.1 i 'one' $<$ OIr. *áiwa- ${ }^{1}$

4.2 ruž 'day' $<$ OIr. *raučah-

4.3 ča 'from, of' < OIr. *hačā- ${ }^{2}$. Most likely in Anbarāni there are two ča, a preposition and the possessive form of the demonstrative pronoun $a$ 'that', i.e. $\check{c} a$

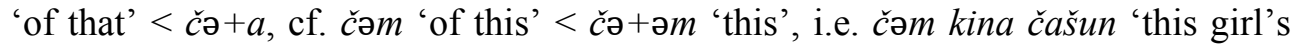
eyes', ča kina čašun 'that girls eyes'. As for the preposition $\check{c} a$, in this case, it can be assumed that this would be the same $\check{c}$ ə, where the sound change: $\partial \rightarrow \mathrm{a}$ has taken place influenced by $\check{c} a$. In the earlier stages of the Talyshi language the functions of today's $\check{c} a$ were performed by $\check{c}$ ə. This is proved by the fact that the form čə is still preserved in čəmān, the possessive personal pronoun of the $1^{\text {st }}$ person singular, which is formed by the preposition čə and $m \bar{a} n$, the oblique form of $1^{\text {st }}$ singular personal pronoun $\bar{a} z$. Despite the fact that in my text corpus there is not any example of čə, it seems that it is still rarely used in Anbarāni. Daniel Paul in his work entitled "A Comparative Dialectical Description of Iranian Taleshi" gives a couple of examples of the preposition $\check{c}$ ə, i.e. cə də gəlau ku ilayə piana? 'which one of the two do you want?'.

\footnotetext{
${ }^{1}$ Rastorgueva, Edelman 2000: 135.

${ }^{2}$ Rastorgueva, Edelman 2007: 301.

${ }^{3}$ Paul 2011: 154. In the description of this sentence D. Paul defines $\check{c} \partial$ (cə) as 3S.POSS, i.e. the third-person singular possessive pronoun, and in the sentence bâla merd cə hân=u pe-kâ 'the child woke the man up' (lit. the child woke the man of the dream, Paul 2011: 160) $\check{c}$ ə (cə) is described as POSSD.3S (the abbreviation POSSD is not found in the list, but most likely it means "possessive form of the demonstrative pronoun"), but it is obvious that in these sentences we deal with the preposition $\check{c}$ z combined with the postposition $u$, since, firstly, the only form of the possessive pronoun for the third-person singular in Anbarāni is čavə, which consists of the preposition $\check{c} \partial$ and the oblique form of the $3^{\text {rd }}$ person singular personal pronoun $a v$. The same goes for the possessive form of
} 
The preposition $\check{c} a$ is rarely used independently in Anbarāni, but based on the few examples from our database a conclusion can be made that it combines with nouns in oblique case and marks the possessor, e.g. ča zua nana uma the mother of the boy came', mān ə ča Ahmadə dadam vinde 'I saw Ahmad's father', but the use of $\check{c} a$ in such constructions is optional (see the comments on do).

$\check{C} a$ also combines with various postpositions such as $k u$, sa (see $\S 4.13$ ), but most likely it only strengthens the meaning of those postpositions with which it combines, and in this case the usage of $\check{c} a$ is optional ${ }^{4}$.

Although the phrase $\check{c} a$ veyza do žio can easily be understood as 'under that walnut tree', but it is obvious that in this case we deal with the preposition ča, not the possessive form of $a$, since $i$ ruž Mallo ča veyza du žio həta bə is the first sentence of the story and the walnut tree is mentioned in the text for the first time.

4.4 veyz 'walnut' $<$ OIr. *gauza- ${ }^{5}$

4.5 do 'tree' < O Ir. *dāru-. In the noun phrase veyza do 'walnut tree' the words veyz 'walnut' and $d o$ 'tree' are linked to each other by the connective vowel $-a$ which in Anbarāni (as well as in other Central and Southern Talyshi dialects) usually links attributive adjectives to nouns, e.g. šin- $a$ angə 'sweet grapes', māhbub-a kina 'beautiful girl' etc. In Anbarāni, as well as in Talyshi dialects spoken in the Republic of Azerbaijan ${ }^{6}$, sometimes nouns can also take -a when they are in attributive position and have adjectival value, e.g. əm žen-a kif xayli čok-e 'This woman's bag is very good', this is exactly as happens in our text.

4.6 žio 'under' $=$ ži $<$ OIr. *hača-adari $+\mathrm{o}<$ OIr. ${ }^{*}$-at ${ }^{7}$. The postposition žio in Anbarāni always combines with the oblique form of nouns. Anbarāni nouns in the oblique case are marked with the suffix $-0^{8}(=$ Az.Tal. $-i)$. The morphological distinction between the direct and oblique cases disappears when a word ends by a vowel, cf. žen ə bālā 'the woman's child', kina bəva 'the girl's brother'.

One of the main functions of the oblique case is the expression of possession (as in the above-mentioned examples). Sometimes it can be expressed also through the combination of the preposition $\check{\boldsymbol{c}} \boldsymbol{a}$ and the oblique case marker -əo

the demonstrative pronoun $a$, which is $\check{c} a<\check{c} z+a$, and not $\check{c} a$. Secondly, the use of those forms is not relevant in this case, while the use of the preposition $\check{c} \partial$ with $-u(=\mathrm{Az}$.Tal. $o)$ is completely logical, it expresses the meaning of the ablative case and is attested in other varieties of Northern Talyshi (see Miller 1953: 75-76, Pireyko 1991: 166).

${ }^{4}$ Probably the fact that $\check{c} a(\check{c} z)$ is not even mentioned in the works on Anbarāni by D. Paul (Paul 2011: 172-174) and R. Amiriān-Budālālu (Amiriān-Budālālu 2005: 53) can be considered as an indicator that the use of this preposition is marginal.

${ }^{5}$ Tsabolov 2001: 409-410, Rastorgueva, Edelman 2007: 257

${ }^{6}$ Miller 1953: 73.

7 Miller 1953: 75; Stilo 2006: 325. According to L. Pireyko (1991: 168) Northern Talyshi $o$ corresponds to the postposition $r \bar{a}$ in all the Tati dialects and both derive from OIr. *radi.

${ }^{8}$ The oblique case marker -ə of Anbarāni corresponds to the suffix $-i$ in other Talyshi dialects, and B. Miller (1953: 79) claims it derives from Old Persian demonstrative particle hya. According to W. Schulze (Schulze 2000: 17) it corresponds to Old Persian -ahyā (genitive singular of a-stems), which in its turn derives from Old Iranian case ending *-ahya (Windfuhr 1992: 29). 
(ø after a vowel), e.g. $\check{c} a$ Ahmadə dada 'Ahmad's father', ča merdə $k a$ 'the man's house', ča do liva 'the leaf of the tree' etc. (see the comments on $\check{c} a)$. Thus, in the noun phrase ča veyza do žio 'under the walnut tree' the word do is in oblique case, even though it is not morphologically expressed.

4.7 həta bə '[he] was asleep'. Həta is the past participle" of the verb həte 'to sleep' $\left(<\right.$ OIr. * $\left.x^{w} \overline{a p t a}-\right)$ and $b$ ə is the $3^{\text {rd }}$ person past form of the Auxiliary verb be 'to be'. This construction, when the past participle of some stative verbs are used as adjectives with the verb be, should not be confused with the past perfect tense of intransitive verbs. Past perfect tense of intransitive verbs in Anbarāni is formed with the past participle followed by the past simple forms of be $(1 \mathrm{sg}$. bim, 2sg. biš, 3sg. bə, 1pl. bimon, 2pl. bin, 3pl. bin), e.g. ša bim 'I had gone', oma biš 'you had come', ogārda bə 'he had come back' etc. Thus, the sentence $i$ ruž Mallo ča veyza do žio həta bə should be translated as 'one day Mullah was asleep under the walnut tree' rather than '... had slept/had fallen asleep...'.

4.8 ki 'that'. $K i$ in Anbarāni is a universal subordinate conjunction for introducing relative clauses ( $a$ žen ki ayo nəšta Mariame 'The woman who is seating there is Mariam'), as well as various completive clauses ( $\bar{a} z$ buva kānanim $k i$ avun uman 'I don't believe that they have come', ama ba nanamun vota ki to dazdišs 'We have told our mother that you are a thief'). Like in Persian ki functions also as emphatic ${ }^{10}$ and can be translated into English by words 'well' or 'so' or through interrogative expressions. In our text, in the sentence ama ki šukr kārdeš pinani the conjunction $k i$ is emphatic and can be translated as either 'Well/So there is no need to thank' or 'There is no need to thank, is there?'.

4.9 i karanda 'suddenly' $=\mathrm{i}$ 'one' + kara 'an instance or occurrence, time' + anda $<$ OIr. *antar 'in, with'.

4.10 gəle 'a, one'. Definiteness is not a specific category in Anbarāni: definite nouns are devoid of any morphological markers and are used in their direct form, e.g. kina xayli māhbub ba 'The girl was very beautiful'. Sometimes definiteness can be optionally marked by demonstrative pronouns, e.g. a žen uma 'The (that) woman came'. In contrast to this indefiniteness is expressed by a special marker, the word gale/gala or ila, e.g gale dazda avunəš kašte 'A thief killed them', am deyoanda ila jazira heste 'There is an island in this sea' etc. According to Professor Boris Miller this word is likely consisted of the numeral $i(g)$ (see $\S 4.1$ )

\footnotetext{
${ }^{9}$ Past participle is constructed by the addition of the suffix $-a$ to either the Pst. or Cst., e.g. kārda 'done', mārda 'dead', hārda 'eaten' etc. Anbarāni past participle corresponds to those of Classical Persian and New Persian with the endings $-a$ and $-e$ respectively, and derives from OIr. participle ending with *-ta followed by the suffix *-ka (e.g. *karta-ka) (see Yefimov, Rastorgueva, Sharova 1982: 169)

${ }^{10}$ Chodzko for the Persian emphatic ke suggested the translation-meaning 'voila, mais, eh bien' in French, for details see Windfuhr 1979: 70-72
} 
and $l a$, which isn't used separately in Talyshi and is related to Persian $l \bar{a}$ 'layer' which also metaphorically means 'times', e.g. $\check{c}$ and $l \bar{a}$ 'several times' ${ }^{11}$.

4.11 agənina '[it] falls', $3{ }^{\text {rd }}$ person singular of the present indicative of the verb aganie "to fall"'. In Anbarāni, in contrast to the Talyshi dialects spoken in the Republic of Azerbaijan ${ }^{12}$, the present tense of the indicative mood is formed from the present stem of the verb (or from the common stem of one-stem verbs ${ }^{13}$ ), the postposition $-n a$, which is probably derived from the postposition anda $(>*$ anna $>$ $-n a$ due to the assimilation), and the following personal endings: $1 \mathrm{sg}$. $-m, 2 \mathrm{sg} .-\check{s}$, 3 sg. $-y$; 1 pl. $-m u n, 2$ pl. $-n, 3 \mathrm{pl}$. $-n$. For the form of $3^{\text {rd }}$ person singular, like in this case, the personal ending is often omitted.

4.12 sa 'head' < OIr. * sarah $^{14}$

4.13 ča sasa 'on the head'. In Anbarāni there is also a postposition sa 'on, on top of', which, can be considered as a result of a semantic expansion of the noun $s a$ 'head'. The postposition $s a$ can be used both independently and along with the preposition $\check{c} a$ as in our text. $S a$ combines with the nouns in oblique form, e.g. $b \bar{a}$ do $s a$ 'on/on top of the mountain', but since the noun $s a$ 'head' ends with a vowel, it is used in its direct form. Thus, in the phrase ča sasa the first $s a$ means 'head' and the second one derives from the same noun and functions as a postposition meaning 'on, on top of'.

4.14 čayo 1. 'there, from there', 2. 'then' = preposition $\check{c} a$ 'from, of' + ayo 'there'.

4.15 šuruš kā '[he] began', $3^{\text {rd }}$ person singular of the simple past tense indicative of the verb šuru kärde 'to begin'. The formation of the simple past tense of transitive verbs differs from that of intransitive, which is due to the existence of split ergativity in Anbarāni. Transitive verbs form their simple past tense from the past stem of two-stem verbs or the common stem of one-stem verbs, followed by the enclitic pronouns (1sg. -əm, 2sg. -ə/-e, 3sg. -əš; 1pl. əmun, 2pl. -ən, 3pl. -əšun)

\footnotetext{
${ }^{11}$ Miller 1953: 128

${ }^{12}$ In all Northern Talyshi dialects of the Republic of Azerbaijan the present tense of the indicative mood is formed from the infinitive by adding the personal endings, which are almost the same as in Anbarāni (except of slightly different form of 1pl with $o$ (-imon), instead of Anbarāni $u$. In these dialects there are different forms for 2pl. and 3pl., while in Anbarāni the $2^{\text {nd }}$ and $3^{\text {rd }}$ plural persons have the same ending).

${ }^{13}$ It is well known that the two-stem verbal system is highly typical for Iranian languages and is considered as 'remarkably stable characteristic, one of the deepest traces of genetic unity across the family' (Haig 2008: 9-10). In spite of the fact that the opposition of two stems, past and present, still is found in Anbarāni, it is significantly blurred and the most of the verbs have lost one of the stems and at the present stage of the language development have only one common stem. Although the same verbs can differ from each other in Anbarāni and Northern Talyshi dialects of Azerbaijan from the perspective of how many stem numbers they contain (for example the verb gārde 'to move, to walk' has one stem in Az.Tal. (Pireyko 1976: 49), while it still preserves the two-stem paradigm in Anbarāni, e.g. $\bar{a} z$ gār-na-m 'I walk', av gārd-e 'he/she walked'), the situation of the verb system in two varieties is almost the same (for much more detailed information see Kaye 2013)

${ }^{14}$ Cheung 2002: 223
} 
functioning as personal endings, and the marker $-e^{15}$ comes next, e.g. vindame 'I saw', havātamune 'we sold' etc. It should be noted, that the enclitic pronouns can be easily detached from the verb and attached to the other members of the sentence, and the marker $-e$ attaches to the verb stem, e.g. ta vindame or ta-m vinde 'I saw you', ila go vindamune or ila go-mun vinde or even ila-mun go vinde 'we saw a cow'. The detaching of the enclitic pronouns from the main verb can also lead to the omission of the marker $-e$, especially when the verb stem ends with a vowel.

As for the N+V compound verb šuru kärde 'to begin' in our text, which is used in the simple past tense and appears as šuruš $k \bar{a}$, the $3^{\text {rd }}$ singular enclitic pronoun has been detached from the verb kārde 'to do' and attached to the noun šuru 'start, beginning', and since it ends with the vowel $u$, the vowel -a of the $3^{\text {rd }}$ singular enclitic pronoun is omitted. This process has caused the omission of the marker -e. It is noteworthy that instead of the past stem $k \bar{a} r d$, we have the present stem $k \bar{a}$. In spite of the fact that $k \bar{a} r d e$ is considered as a two-stem verb ${ }^{16}$, it undergoes the process of losing two-stem paradigm and converts into one-stem verb with the stem $k \bar{a}$. For example, the future tense of the indicative mood in Anbarāni is built by the prefix $b a-$, the past stem and the personal endings. In case of the verb kārde the stem $k \bar{a}$ is used for the future tense: bakām 'I will do', bakāšs 'you will do', bakāy 'he/she will do' etc.

4.16 ba 'to', cf. NP. be.

4.17 šukr kārde 'to thank', from Ar. šukr 'thankfulness, gratitude'

4.18 nafar 'person'. In all probability this is a new loanword of Arabic origin borrowed from Persian, since the world-final liquid $r$ is not dropped which is typical not only for inherited Talyshi words (see $§ 4.31$ ), but also borrowings, like xaba 'news' < Ar. xabar, xəyo 'cucumber' < NP. xiyār , etc.

4.19 davāna bə '[he] was passing', $3^{\text {rd }}$ person singular of the past imperfect $1^{17}$ tense of the verb davārde 'to pass'. Its formation is quite similar to the present

${ }^{15}$ B. Miller (1953: 168) compares this marker with NP. ast and claims that it should be considered as copula. D. Stilo (2008: 374) defines it as the $3^{\text {rd }}$ person singular enclitic form of the auxiliary verb, while D. Paul (2011: 137) calls it transitivity marker.

${ }^{16}$ see Paul 2011: 104 for Iranian Talyshi, Pireyko 1976: 117 for Talyshi spoken in the Republic of Azerbaijan.

${ }^{17}$ Daniel Paul calls this tense "Past Progressive" (Paul 2011: 125), so does Donald Stilo speaking about the analogical form in Azerbaijani Talyshi (Stilo 2008: 385-388). Doubtlessly this tense expresses progressiveness/continuousness, indicating an action that was ongoing at the past time being considered, e.g. a vaxti ki av ogārde, āz kitob bim hānna 'when he came back, I was reading a book'. In this case this tense fully corresponds to the past continuous tense of English or Persian, but at the same time in Anbarāni the habitual aspect combined with the past tense as well can be expressed through this tense, e.g. pona āz hā māng ba rustā šina bim 'last year every month I went to the village', or av hamiša omina bo ba čama ka o gap bimun žana 'he always came to our house and we talked'. This shows that this tense expresses imperfectivity in general, including iterativity, habituality and progressivity, and since all these can be considered as types or subcategories of imperfectivity (see Comrie 1976: 25), it would be more correct to call this tense 'Past Imperfect'. 
tense, i.e. the present stem (or the common stem for one-stem verbs) and the postposition -na are used in this case as well, and the opposition over the present tense is expressed through the auxiliary be 'to be', which is used in the past perfect and indicates the person and number of the subject: 1sg. bim, 2sg. biš, $3 \mathrm{sg}$. ba, $1 \mathrm{pl}$. bimun, 2pl. bin, 3pl. bin, e.g. šina bim 'I was going', kāna biš 'you were doing', šama vona bin 'you (pl.) were saying', avun ogārna bin 'they were returning' etc. This form is the same for both transitive and intransitive verbs.

4.20 A vāxti ki 'when' < DEM. $a$ 'that' $+v \bar{a} x t$ 'time' $+i^{18}+$ CONJ. $k i$ 'that'. As Rubinčik ${ }^{19}$ claims about the Persian analogue of a vāxti ki (NP. vaqti ke 'when') from which most likely the Anbarāni version is calqued, this compound conjunction is actually a phraseological combination consisting of correlative words and the universal subordinating conjunction $k i$, but there are also two significant differences between these forms: while the Persian conjunction can be used without $k e$ and in the same time the use of $y \bar{a}-y e$ ešarat (i) is mandatory, in the Anbarāni form $k i$ can't be omitted and $i$ is optional, e.g. a vāxt ki žen ba ka rase cava merd ba ko ba ša 'when the woman got home, her husband had gone to work'.

4.21 yaziya 'incident, bad luck', Arabic borrowing, cf. Ar. qadiyya 'case, lawsuit'.

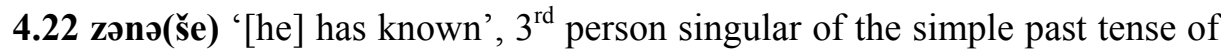
the verb zane 'to know, to learn' < OIr. *zana- . In the verb phrase yaziyaš zane, as it appears in the text, the enclitic pronoun -əš has been detached from the verb and attached to the object yaziya of the ergative sentence, and the marker -e has been preserved and directly attached to the stem zan-.

4.23 vote '[he] said', $3^{\text {rd }}$ person singular of the simple tense of the verb vote 'to say' < OIr. ${ }^{*}$ waxta $^{20}$. We have already discussed the formation of the simple past tense of transitive verbs. The verb vote 'to say' has the following paradigm for the simple past tense: $1 \mathrm{sg}$. votวme 'I said', 2 sg. vote ${ }^{21}$ 'you said', 3sg. votวše

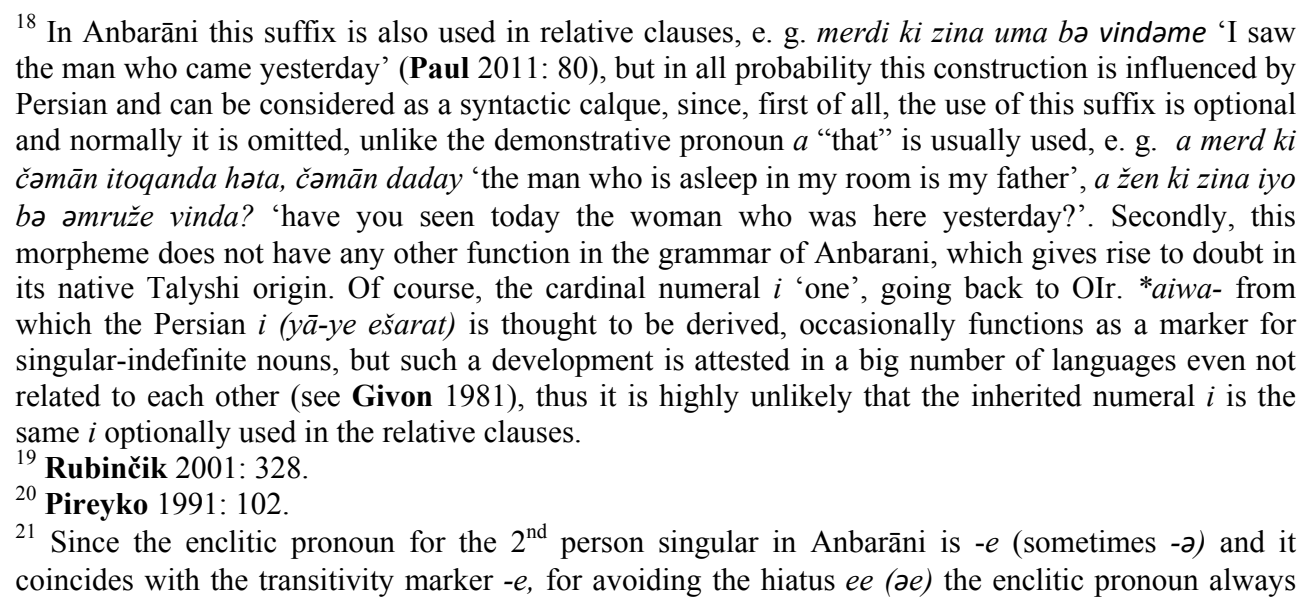


'he/she said', 1pl. votzmune 'we said', 2pl. votane 'you said', votəšune 'they said'. In the sentence $b a$ Malloš vote '[he] said to Mullah', the personal ending is detached from the verb and attached to the indirect object Mallo, the marker -e is attached to the past stem -vot.

It is interesting that in the last sentence of our text in the clause Mallo vote 'Mullah said' the verb vote occurs without the pronominal clitic -əš which would indicate the person and number of the agent. Most likely this is similar to the case when in Anbarāni and also in the Northern Talyshi dialects spoken in the Republic of Azerbaijan in a completely clear context, both the overt agent and the enclitic pronouns can be omitted ${ }^{22}$. In this case the $3^{\text {rd }}$ person singular of the simple past tense of a transitive verb coincides with the form of the same person, number and tense of an intransitive verb, but, as it was mentioned above, in the case of transitive verbs $-e$ is the transitivity marker, while in the case of intransitive verbs $e$ is $3^{\text {rd }}$ person singular personal ending, and if the agent (the subject of nominative sentences) is not omitted, it is used in oblique case with transitive, and in direct case with intransitive verbs, e.g. ava vote 'he/she said', but av vite 'he/she ran', Ahmadə pāte 'Ahmad cooked', but Ahmad hate 'Ahmad slept'. The simple past tense of intransitive verbs in Anbarāni is formed with the past stem of two-stem verbs or the common stem of one-stem verbs by adding the following personal endings: 1sg. -im/-em, 2sg. -iš, 3sg. -e, 1pl. -imun/-emun, 2pl. -in, 3pl. -in, e.g. šim 'I went', davārdiš 'you (sg.) passed', avun māndin 'they stayed' etc.

4.24 əmə the oblique form of DEM. am 'this' < OIr. *ima-.

4.25 pinani '[it] doesn't want, doesn't need'. The verb pie, which means 'to love' and 'to want', holds a special place in the verbal system of Anbarāni (and generally in Northern Talyshi ${ }^{23}$ ) this verb shows an ergative pattern not only in the simple past, present perfect and past perfect tenses, but also even in present tenses (actually this is not a unique phenomenon in Iranian languages ${ }^{24}$ ). If considered out of the sentence, pinani looks like a negative form ${ }^{25}$ of the $3^{\text {rd }}$ person singular of any other verb (no matter transitive or intransitive) in the present tense of the indicative mood, cf. šinani 'he/she doesn't go', hatnani 'he/she doesn't sleep', vārnani 'he/she doesn't bring', gatnani 'he/she doesn't take' etc. Actually, the complete form for 'he/she/it doesn't want' in Anbarāni is pinaniše, which, unlike the other verbs with -ø ending after the negative particle $-n i$, obtains $-(\partial) \check{s}$ and the transitivity

detaches from the verb and attaches to other parts of the sentence (except of the agent), e.g. to keyna ava vinde? 'when did you see him?'. But if the clause consists of only the agent and the predicate, the enclitic pronoun is omitted, e.g. to vote: bo iyo 'you said: come here!'. In this case the $2^{\text {nd }}$ person singular form of the verb in the simple past tense is exactly the same as $3^{\text {rd }}$ person singular in a clause with a completely clear context, such as Mallo vote 'Mullah said'.

22 see Paul 2011: 139, Stilo 2008: 382.

${ }^{23}$ see Miller 1953: 182, Stilo 2008: 369.

${ }^{24}$ see Haig 2008: 305.

${ }^{25}$ See the comments on $\$ 4.28$ 
marker -e. The sentence ama ki šukr kärdeš pinani 'well, there is no need to thank' (lit. 'this does not want thanking') shows an ergative pattern: the agent am is used in oblique case, the direct object, which is the infinitive of šukr kärde, has not been changed morphologically since it ends with a vowel, but the personal ending -əš is detached from the verb and attached to the direct object, and the marker $-e$ is omitted.

\subsection{6 hāy 'hey!'.}

4.27 $\overline{\mathbf{a} x m a x}$ 'fool'. Obviously, an indirect Arabic loanword with a Turkic source as intermediary, which is indicated by the first consonant $x$. The original Arabic word $a h m a q^{26}$ was borrowed by Persian, but most likely Persian was not the source for Anbarāni loanword āxmax, since the consonant $x$ in Northern Talyshi is relatively less active and even in the loanwords the original $x$ tends to change into $h$, e.g. Ar. xayr $>$ hayy, xāsiyat $>$ hosiyat ${ }^{27}$. Instead the sound change $\mathrm{h}>\mathrm{x}$ is found in a number of Turkic languages, e.g. Tab. $\operatorname{axmax}^{28}$, Az. āxmāq ${ }^{29}$, Gr. Tat. $\operatorname{axmax}^{30}$ $\operatorname{etc}^{31}$. The Kurdish $\bar{a} x m \bar{a} x, \bar{a} q m \bar{a} q$ is also defined as an Arabic borrowing through a Turkic source by R. Tsabolov' 32 .

4.28 zənaniš 'you don't know'. The negative form of the $3^{\text {rd }}$ person singular of the verb zane 'to know'. The negative forms of the present tense are built by adding the negating particle $n i$ between the postposition $-n a$ and the personal endings, e.g. šinanim 'I don't go/I am not going', bārnani(y) 'he doesn't take/he's not taking', avon vitnanin 'they don't run/they aren't running' etc. The verb zane has one stem, zan, but instead of the expected form *zannaniš we have zananišs. Obviously after adding the posposition $-n a$ to the verb stem which ends with $n$, the cluster $n n$ is degeminated to $n$. But it seems this happens only during the negation, most probably under the influence of the negation particle $n i$, because both in my corpus and in the work of D. Paul the affirmative forms of the present and past imperfect tenses preserve cluster $n n$, e.g. $\bar{a} z$ zannam ki əštə pia dada xayli čuka merde 'I know that your grandfather is a very good person'.

4.29 agar 'if', most likely a Persian borrowing going back to OP. *hakaram.

4.30 avaz 'instead', loanword of Arabic origin.

4.31 xāmza 'melon'. Obviously this is a Southwestern Iranian, most likely Persian borrowing in Anbarāni, cf. NP. xarboze 'melon'. There are two theories on the etymology of the Persian word. The first is that the word means 'donkey

\footnotetext{
${ }^{26}$ see, for example, Steingass 1972: 17.

${ }^{27}$ Pireyko 1991: 114.

${ }^{28}$ Salimi 1976: 102.

${ }^{29}$ Tağı̀ev 2006: 72.

${ }^{30}$ Podolsky 1985: 3.

${ }^{31}$ The word ufuu ułu [axmax] is broadly used in colloquial Armenian and in a number of dialects. Ačarean (Ačariean 1902: 65) determines the word as a Turkish loanword of Arabic origin in the Armenian dialects of Constantinople, Van and Artsakh.

${ }^{32}$ Tsabolov 2001: 102.
} 
cucumber' and derives from Middle Persian kharbuzak, xarbōjīn $\bar{a}^{33}$, while supporters of the second theory claim that the word is an Old Indo-Aryan loanword, it originates from trapusa which was changed into xarbuzza under the influence of the folk etymology ${ }^{34}$. Even if the Persian xarboze is derived from Early Middle Persian xarbūčak ${ }^{35}$, which in its turn consists of the roots xar 'donkey ${ }^{36}<$ OIr. *xara- and *bučak 'cucumber', it can be considered as an inherited Persian word. The same can not be told about Anbarāni xāmza, since the consonants $x$ and $z$ in it indicate that it is borrowed from a Southwestern Iranian source. As we know in Northern Talyshi at the beginning of the inherited words * $x$ regularly changes into $h$, as in Anb. $h a$ 'donkey' < OIr. *xara- ${ }^{37}$, Anb. harie 'to buy' < OIr. ${ }^{*} x r i-n a^{38}$, and we should have $\check{z}$ instead $z$, which is a well-known isogloss between Northwestern and Southwestern Iranian languages ${ }^{39}$, e.g. in ruž 'day' < OIr. *raučah- 'light, day', cf. Prth. rōž, MP. rōč, rōzz" NP. ruz, Anb. rəže 'to collapse, to crumble' < OIr. *raiča < PIE. *leik ${ }^{\mathrm{w}}-$ 'to leave, to abandon' ${ }^{41}$, cf. NP. riz, Prst. of rixtan 'to pour'.

The liquid $r$ is very unstable in Anbarāni (and generally in Northern Talyshi in contrast to Southern Talyshi dialects ${ }^{42}$ ), while it is well-preserved at the beginning of the words, e.g. ruž 'day' < OIr. *raučah-, ravos 'fox' < OIr. *raupasa- etc., it is usually lost in middle and final position, both in inherited words and borrowings, e.g. ko 'work" < OIr. *kāra-, cf. NP. kār, poa 'part, portion' < OIr. *pāra-, cf. NP. pāre, xaba 'news' < Ar. xabar, deyu ${ }^{43}$ 'sea' < NP. daryā, xəyo 'cucumber' < NP. $x i y \bar{a} r, s i$ 'garlic' < NP. sir etc. The lengthening of $a$ into à before $r$ after the loss of it, like in $x \bar{a} m z a$, is not unusual in Anbarāni either, e.g. $k \bar{a} g$ 'hen' < OIr. * $k r k a-{ }^{44}$, cf. Gil. kark, Maz. kerk ${ }^{45}, \check{c} \bar{a} x$ 'wheel' $<* \check{c} a r x<$ OIr. *čaxra-. It is difficult to

\footnotetext{
${ }^{33}$ Horn 1893: 105.

${ }^{34}$ Doerfer 1967: 380, Abaev 1989: 141-142.

${ }^{35}$ Doerfer 1967: 380.

${ }^{36}$ There is also another opinion on the subject that xar- doesn't mean 'donkey', but 'big' (see Abaev 1989: 141, f3), going back to OIr. *kara-/*xara- (see Edelman 2011: 280-282).

${ }^{37}$ Hasandust 2011: 223.

${ }^{38}$ Rastorgueva 1990: 219.

${ }^{39}$ see Paul 1998.

${ }^{40}$ Durkin-Meisterernst 2004: 297-298.

${ }^{41}$ Rastorgueva 1990: 196.

${ }^{42}$ see Bazin 1980: 70.

${ }^{43}$ This word goes back to OIr. *zrayah- 'sea', but doubtlessly it is not an inherited Talyshi word, since the Southwestern Iranian shift of $*_{z}$ to $d$ instead of $*_{z}>z$ (e.g. zane 'to know $<$ OIr. ${ }^{*} z a n-, z u a$ 'boy'< OIr. *zata- etc.) shows that it is actually a Persian loanword, although after borrowing it has undergone typical Northern Talyshi changes as the loss of $r$ and the shift of Persian $\bar{a}$ into o $>\mathrm{u}$ (cf. Az.Tāl. dayo).

${ }^{44}$ Edelman 2011: 398.

${ }^{45}$ Hasandust 2011: 310.
} 
explain the shift of $b$ to $m$, but it is attested also in some other Iranian languages, cf. Tāt. xamza, Mm. hermìze, Vrzn. komze $e^{46}$.

4.32 abi '[if it] was';

4.33 avoyi '[it] would come'. This is the form of the past imperfect $2^{47}$ which has the following formation: prefix $-a+$ verb stem (Prst. or Cst.) + personal endings (1sg. -im, 2sg. -iš, 3sg. -i/-y; 1pl. -imun, 2pl. -in, 3pl. -in). In our text corpus not a single usage of this form is found for expressing the past imperfective $e^{48}$. Just like in this short story, this form always appears in counterfactual conditional sentences and it is used both in protasis and apodosis, e.g. agar havo čuk abi, āz ba boy ašim 'if the weather was good, I would go to garden', agar tə ava aviniš, čič avotiš 'if you saw him, what would you say?' etc. From this point of view the abovementioned form is analogical to the past imperfect of the Persian language, which is also used in a conditional meaning both in if-clause and in main clause.

Note that in the form avoyi between the prefix $-a$ and the stem $o$ the consonant $v$ is inserted, and the consonant $y$ is added between the stem and the personal ending $-i$ to prevent hiatus.

4.33 če 'what'

4.34 balo 'trouble, disaster', Arabic borrowing most likely with a Turkic source as intermediary. The construction če baloyi must be a calque from the Persian language, cf. če

\section{Abbreviations}

1pl. - the first-person singular

1 sg. - the first-person singular

2pl. - the second-person singular

2sg. - the second-person singular

3pl. - the third-person singular

3S.POSS - the third-person

possessive pronoun

3sg. - the third-person singular

Anb. - Anbarāni
Gr. Tat. - Greek Tatar

Maz. - Mazanderani

Mm. - Meime'i

MP. - Middle Persian

$\mathrm{N}+\mathrm{V}$ - a compound with noun+verb

singular NP. - New Persian

OIr. - Old Iranian

OP. - Old Persian

Pa. - Parthian

\footnotetext{
${ }^{46}$ Hasandust 2011: 146.

47 It is noteworthy that during writing this article, I contacted my source of information Sinā Morādzādeh and asked him to translate a sentence from Persian to Anbarani. The sentence already existed in my text corpus, based on my records of the fieldwork conducted in July 2015. My goal was to see if the same form, past imperfect 1 , would be used this time, and I got exactly the same result: NP.. pārsāl man har māh be rustā mi raftam ('last year every month I went to the village') $\rightarrow$ Anb. pona āz hā māng ba rustā šina bim. Then I asked him if 'šina bim' can be replaced by the form 'āšim' (Past Imperfect 2). His answer was: "No, 'ašim' is used in conditional sentences, my friend". Probably this fact indicates that for expressing the imperfective aspect in the past tense, native speakers of Anbarāni prefer to use past imperfect 1, and past imperfect 2 tends to be used only in conditional sentences, thus probably "Past Imperfect 2" is not a very correct way to call this tense and possibly should be replaced by "Past Unreal Conditional".

${ }^{48}$ In D. Paul's work there are some examples of this tense used as past imperfective, see Paul 2011: 129.
} 
Ar. - Arabic

Az. - Azerbaijani

Az.Tal. - Talyshi dialects spoken in the

Republic of Azerbaijan

CONJ. - conjunction

Cst. - common stem

DEM. - demonstrative pronoun

Gil. - Gilaki
PIE. - Proto-Indo-European

Prst. - present stem

Pst. - past stem

Tab. - Tabrizi dialect of Azerbaijani

Tāt. - Tati

Vrzn. - Varzane'i

\section{BIBLIOGRAPHY}

Abaev V. 1989: Istoriko-etimologičeskij slovar osetinskogo jazyka, vol. 4, Nauka, Leningrad.

Ačariean H. 1902: T'urkerēn p'oxareal barer hayerēni mēj (Polis, Vani, Łarabałi ew Nor Naxiǰewani barbarner), Moscow and Vałaršapat.

Amiriān-Budālālu R. 2005: Guyeš-e tāleši-e Anbarān-e Ardabil, Našr-e Jāme'e Negar, Tehran.

Bazin M. 1980: Le Tâlech: Une region ethnique au nord de l'Iran, tome II, Editions ADPF, Paris.

Bazin M. 2012: ‘Anbarān, in Encyclopædia Iranica, $\mathrm{http}: / /$ www.iranicaonline.org/articles/anbaran

Cheung J. 2002: Studies in the Historical Development of the Ossetic Vocalism, Dr. Ludwig Reichert Verlag, Wiesbaden.

Comrie B. 1976: Aspect: An Introduction to the Study of Verbal Aspect and Related Problems, Cambridge University Press, Cambridge.

Doerfer G. 1967: Türkische und mongolische Elemente im Neupersischen, vol. 3, Franz Steiner Verlag, Wiesbaden.

Durkin-Meisterernst D. 2004: Dictionary of Manichean Middle Persian and Parthian, Brepols Publishers, Turnhout.

Edelman D. 2011: Etimologičeskij slovar' iranskix jazykov, vol. 4., Vostočnaja literatura, Moscow.

Givon T. 1981: On the Development of the Numeral 'One' as an Indefinite Marker, in Folia Linguistica Historica, volume 15, Issue Historica vol. 2,1, pp. 35-53.

Haig G. 2008: Alignment Change in Iranian Languages: A Construction Grammar Approach, Mouton de Gruyter, Berlin-New York.

Hasandust M. 2011: Farhang-e tatbiqi-mowzu'i-e zabānha va guyešha-ye irāni-e now, Farhangestān-e zabān va adab-e fārsi, Tehran.

Horn P. 1893: Grundriss der Neupersischen Etymologie, Verlag Karl J. Trübner, Strassburg.

Kaye S. 2013: Morphomic stems in the Northern Talyshi verb: diachrony and synchrony, in S. Cruschina, M. Maiden \& J. C. Smith (eds.), The Boundaries of Pure Morphology, Oxford University Press, Oxford.

Miller B. 1930: Talyškije teksty, RANION, Moscow.

Miller B. 1953: Talyšskij jazyk, Nauka, Moscow.

Paul D. 2011: A comparative dialectical description of Iranian Taleshi, PhD thesis, University of Manchester, Faculty of Humanities. 
Paul L. 1998: The position of Zazaki among West Iranian languages, in Nicholas SimsWilliams (ed.), Proceedings of the Third European Conference of Iranian Studies, part 1, Reichert Verlag, Wiesbaden.

Pireyko L. 1976: Talyšsko-russkij slovar', Russkij jazyk, Moscow.

Pireyko L. 1991: Talyšskij jazyk. Dialekty tati Irana, in Vera Rastorgueva (ed.), Osnovy iranskogo jazykoznanija. novoiranskie jazyki: severo-zapadnaja gruppa, vol 1, Nauka, Moscow.

Podolsky B. 1985: A Greek Tatar-English Glossary, Harrasowitz, Wiesbaden.

Rastorgueva V., Edelman D. 2000: Etimologičeskij slovar' iranskix jazykov, vol. 1, Vostočnaja literature, Moscow.

Rastorgueva V., Edelman D. 2007: Etimologičeskij slovar' iranskix jazykov, vol. 3., Vostočnaja literatura, Moscow.

Rastorgueva V. 1990: Sravnitelno-istoričeskaja grammatika zapadnoiranskix jazykov: fonologia, Nauka, Moscow.

Rubinčik J. 2001: Grammatika sovremennogo persidskogo literaturnogo jazyka, Vostočnaja literatura, Moscow.

Salimi H. 1976: A Generative Phonology of Azerbaijani. University of Florida, Gainesville.

Schulze W. 2000: Northern Talysh, Lincom Europa, Muenchen.

Stilo D. 1981: The Tati language group in the sociolinguistic context of Northwestern Iran and Transcaucasia, in Iranian Studies, vol. XIV, nos. 3-4, pp. 137-187.

Stilo D. 2006: Circumpositions as an areal response: The case study of the Iranian zone, in Lars Johanson and Christiane Bulut (ed.), Turkic-Iranian Contact Areas: Historical and Linguistic Aspects, Harrassowitz Verlag, Wiesbaden.

Stilo D. 2008: Two Sets of Mobile Verbal Person Agreement Markers in the Northern Talyshi Language, in Simin Karimi, Vida Samiian and Donald Stilo (ed.), Aspects of Iranian Linguistics, Cambridge Scholars Publishing, Newcastle upon Tyne.

Tağıyev M. 2006: Azərbaycanca-Rusca lüğət, vol. 1, Şərq-Qərb, Baku.

Tsabolov R. 2001: Etimilogičeskij slovar' kurdskogo jazyka, vol. 1, Vostočnaja literatura, Moscow.

Windfuhr G. 1979: Persian Grammar: History and State of its Study, Mouton Publishers, The Hague-Paris-New York.

Windfuhr G. 1992: Cases, in Encyclopædia Iranica, Vol. V: Carpets-Coffee, Mazda Publishers, Costa Mesa, California.

Yarshater E. 1996: The Taleshi of Asālem, in Studia Iranica, vol 25.1, pp. 83-113.

Yefimov V., Rastorgueva V., Sharova E. 1982: Persidskij, Tadžikskij, Dari, in V. A. Abaev, M. N. Bogolyubov, V. S. Rastorgueva (ed.), Osnovy iranskogo jazykoznanija. Novoiranskie jazyki: zapadnaja gruppa, prikaspijskie jazyki, Nauka, Moscow.

Hakob Avchyan

Yerevan State University hakob.avchyan@ysu.am 


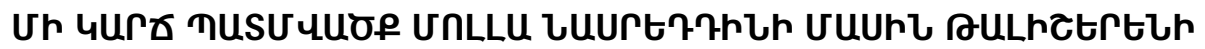

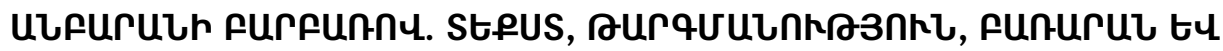

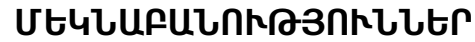

\author{
<ulnn Uysjuir
}

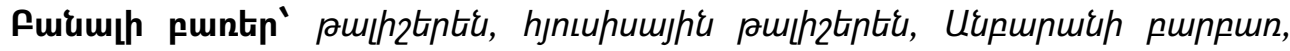

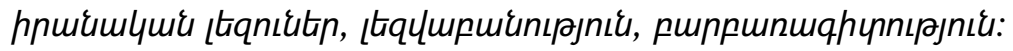

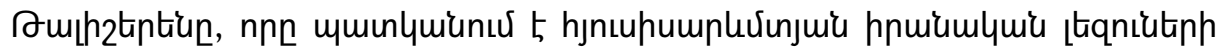

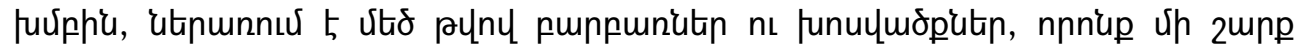

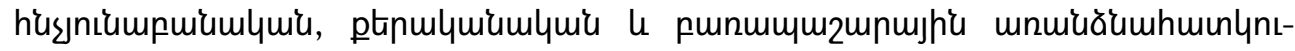

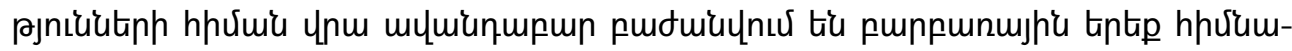

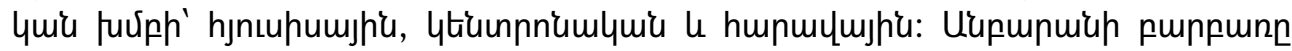

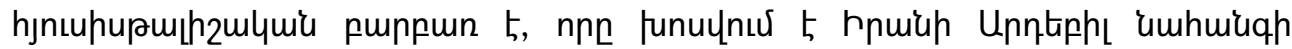

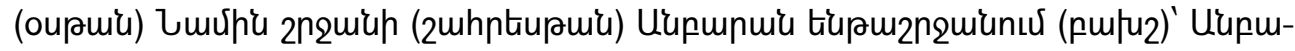

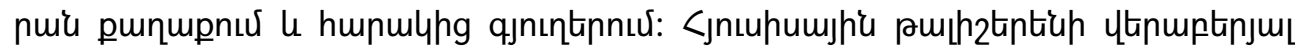

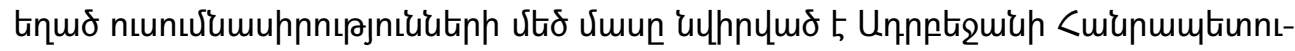

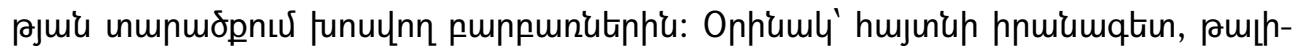

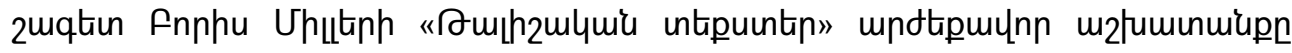

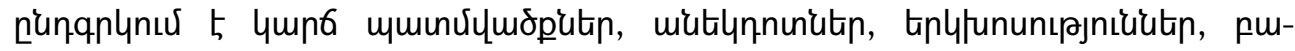

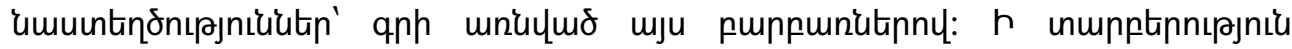

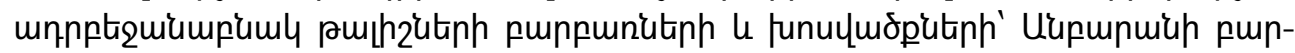

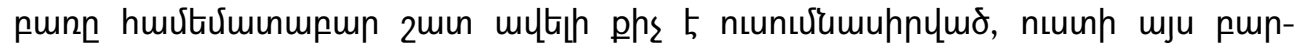
punny hnumwnmly

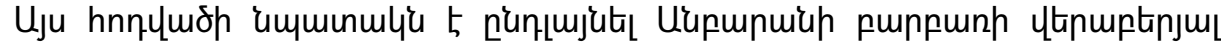

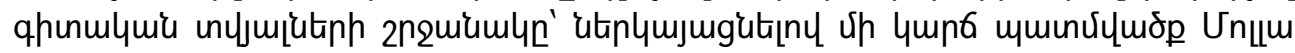

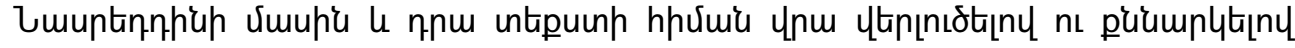

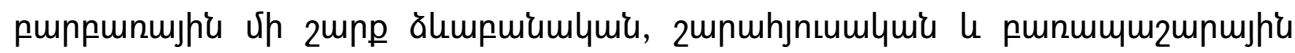

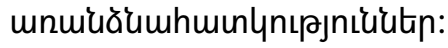

